\title{
Adoption of Koha Integrated Library System (ILS) for the Automation of Umaru Musa Yar'adua University Library, Katsina, Nigeria: Problems and Prospects
}

\author{
Nafi'u Maharazu' ${ }^{1}$ and Suleiman Hamisu Malumfashi ${ }^{2}$ \\ ${ }^{1}$ Department of Library and Information Science, ${ }^{2}$ University Library \\ ${ }^{1 \& 2}$ Umaru Musa Yar’adua University, Katsina, Nigeria \\ E-mail: nafiu.maharazu@umyu.edu.ng, suleiman.hamisu@umyu.edu.ng
}

\begin{abstract}
This study attempted to explore the gradual advancement of modern technology in libraries, it distinguished old and new innovations, creative efforts of librarians and information technologists through the various generations of automation revolution. The study also identify various components of the Integrated Library System (ILS) or Library Management System (LMS) which are used or being used in Umaru Musa Yar'adua University (UMYU) library as well as the services automated by the system. The study also identifies the exact reasons for adopting KOHA in UMYU library. It also explains the impact, challenges associated with the University library automation system. The study adopted quantitative approach as research paradigm; with survey as research methods. Questionnaires were the instrument used for data collection. The population of 42 library staff was used for the study. The data for the study were analyzed using tables and frequencies. From the findings of the study the two main services fully automated were the Circulation and Cataloguing, the library adopted the use of the KOHA ILS as it was a free open source and secondly for greater opportunities and innovation. However, retrospective conversion and Low Level of Literacy were the major challenges and a setback for the KOHA ILS implementation in the library understudy. The study recommended the need for the increase investment in the automation project to speed up the implementation of automation systems.
\end{abstract}

Keywords: KOHA, Library Automation, Open Source Software, Integrated Library System, Automation

\section{INTRODUCTION}

The effectiveness and efficiency of a library service now largely depend upon its level of computerization. Libraries looked toward the use of computers to make the immense voluminous resources more readily accessible to their customers. The objective of automation is highly welcomed development as the world is undergoing technological and digital revolution, characterized by a high level of automation in every aspect of human life. Academic libraries are the heart and the cornerstone of their parent institutions. However, the level of development varies from one organization to another. Without doubt, UMYU library has its own fair share of such development which yielded its early automation. Automation has been orthodox with passionate admiration as a worldwide experience, though there are some areas that need to be improved.
Therefore, going by the vision and mission of the University with its aspiration of becoming one of the best universities in Nigeria with an established reputation and image for high quality teaching, research, innovative and creative learning techniques as well as producing well-grounded, soundminded graduates equipped with problem-solving, decisionmaking and planning skills for self-reliance, All this cannot be efficiently accomplished without automating the library as a means of abundant availability, easy accessibility and utilization of the library's resources as well as a means of facilitating resource sharing among the numerous available institutions.

UMYU Library is made up of the Main Library, which contains a collection of selected books and periodicals in different subject areas of programmes offered by the University. It also complements its services with e-Library facilities comprising over 200 Desk-top computers fully connected to the internet as well as an eGranary digital library system containing an off-line collection of approximately 30 million educational resources. In addition to the Main Library resources, there are five faculty libraries fully equipped with books and e-Library facilities that are linked to the main Library via the intranet (University library guide, 2012).

\section{STATEMENT OF THE PROBLEM}

University libraries in Nigeria have had a long history of trying to computerize their services. Most have not made appreciable efforts at this. The major problem always linked to software selection issues; acquisition and maintenance drive their automation projects. This has been a worrisome for libraries to function under a standardized platform for information storage, access and utilization. Oladokun (1992) opined that the task of choosing software for a library is often difficult, because the software must be sufficiently powerful and capable with all library processes and a user-friendly. Okentunji (2006) pointed out that for libraries to make maximum use of automation a number of requirements must be fulfilled. One of the requirements has to do with the selection of software. 
Some of the problems include inadequate technical support from the software vendors or their technical representatives in the country. Also lack of thorough feasibility study and improper consultations among stakeholders involved. All these have led to failure of automation projects. These failures may result in abandonment of the project sometimes fresh start when new software is chosen. It is therefore against this background that the researchers investigated the adoption of KOHA software for the automation of Umaru Musa Yar'adua University library to examine the success or otherwise.

\section{OBJECTIVES OF THE STUDY}

1. To identify the Various Components and Stages of Automation Development of KOHA System of UMYU Library Operations.

2. To Ascertain the Reasons for the Adoption and Implementation of KOHA in UMYU Library.

3. To Explore the Challenges and Experience of KOHA Implementation Project.

\section{RESEARCH QUESTIONS}

1. What are the Various Components and Stages of Automation Development of KOHA system of UMYU Library Operations?

2. What are the Reasons for the Adoption and Implementation of KOHA for Automation of UMYU Library?

3. What are the Challenges and Experience Associated with KOHA Implementation Project in UMYU Library?

\section{REVIEW OF RELATED LITERATURE}

KOHA originated from the Maori term meaning 'gift', donation or contribution”. KOHA is a web-based ILS with Structured Query Language (SQL) database, cataloguing data stored in MRAC and accessible via Z39.50 (Microsoft ( Encarta ${ }^{\circledR}$ 2009),

Library automation encompasses the operation of the library which is performed by computers, which perform traditional library operation activities such as acquisition, circulation, cataloguing, reference and serial control. Automation makes library resources easier for users to locate as well as allowing library staff to achieve better services by facilitating a multitude of staff tasks such as acquisitions, cataloguing, circulation and reference. Automation cannot be approached as a panacea for systemic problems in a library (Sheikh, 2011).

As cited by Jan and Sheikh (2011), in Dilroshan (1998) says that automating library is only the first step, but keeping up with new trends in information and communication technology is also of paramount importance. Nok (2006) observes that the triumph of any automation project in university libraries depends largely on the ability of the staff to facilitate and implement the process. Proper, frequent and regular in-house IT training is necessary if the maximum benefit is to be gained from the automation of library services. It was further added that for a sound quality automation to be accomplished, more attention should be by the libraries to the issue of user education, provision of continuing education for library staff.

In a similar development, a lot of literature on library automation in Nigerian universities indicates that most libraries depend on free and donated software for their automation projects. There has never been concerted effort at a systematic feasibility study of the fundamental requirement of automation procedures and plans (Imo, 2011).

Experience has shown that issues of inappropriate choice of software for automation projects in libraries have contributed immensely to the failures of automation projects, hence there is evidence of software turnovers in some libraries automation projects. Research on library automation in Nigerian universities has always taken a holistic approach to the issue. They have always taken issues of hard ware, peripherals and software together not separating the contributions of each to the successful implementation of automation projects.

\section{THE COMPONENTS OF KOHA SYSTEM}

KOHA according to Kumar (2012) can be used in any kind of library irrespective of their size. It is a true enterprise class ILS with various features which includes modules for circulation, cataloguing, serials management, acquisitions, reserves, patron management, branch relationships, and more as follows:

\section{A. Acquisition}

Acquisition module is in the transition process and lots of changes have been added to the latest version. Improving Budget and effective allocation of funds will help to give control over library expenditures.

\section{B. Serials Management}

Serials management module does not connect with budget and it lacks article indexing features. Due to these reasons, a serials management module could find much acceptance among KOHA users. Only $7.41 \%$ of respondents rated it excellent while $11.11 \%$ stated that the serial management module is relatively poor.

\section{Cataloguing/Classification}

KOHA used of MARC 21, UNIMARC standard for cataloguing practices. It also attached Z39.5 as standard for downloading, cataloguing information from remote library servers (e.g. Library of Congress). It displays all MARC fields and users have to customize it to minimum number of 
fields required for the library. Among KOHA users, 32.1\% indicate ease of cataloguing as excellent while $53.57 \%$ indicate as very good.

\section{Circulation}

The circulation module of KOHA was the most highly rated module with $51.72 \%$ rating it as excellent. A circulation process in KOHA is time saving and it helps to complete the circulation transactions with ease. Circulation module options are attached to the universal task bar and library staff can easily switch to check in or check out of documents during other works.

\section{E. Management}

This includes, Mailing, Scheduling and Statistics/report

\section{REASONS FOR THE ADOPTION OF KOHA ILS}

The main purpose of the project is to implement a complete library automation system using open source software KOHA and develop ourselves as a local resource.

Other intentions of the project are to convert data from the existing library systems into standard format (MARC 21) that will preserve and insure its continued development and preservation, as well as the ability to migrate data to new generations of library systems which will enable us rapid communication with other libraries (including outreach libraries).Ibid.

KOHA is an open source project. That means its source code is open. Anyone can develop from anywhere in the world at any time. And, with the help of open source developers, now KOHA is known as the most powerful ILS in the world of Information \& Library system. Moreover, KOHA has some advantages over other ILS. Some of the reasons for the adoption of KOHA include:

1. Dual Database Design: KOHA uses two database design, which makes it more stable \& industry standard. It supports both text based \& Real time database management system.

2. Library Standards Compliant: KOHA is capable of the interoperability between KOHA and other systems and technologies, while supporting existing workflows and tools.

3. Web Based Interface: KOHA has a very user friendly web based interface. And it is using all the cutting edge web technologies like XHTML, CSS \& Java script.

4. Robustness: The public front-ends should be sufficiently stable to avoid a situation where a poorly done operation (badly formed query, etc.) could bring down the system.

5. Usability: The Online Public Access Catalogue (OPAC) had to be immediately useful to the walk-up patron.
6. Basic Performance: The average query had to be handled quickly enough to meet expectations (while difficult to assign a metric, feedback on this would be continuous if this aspect was neglected).

Therefore, in 2010, the UMYU library adopted KOHA ILS to enhance easy access to the library collection. The choice of KOHA by UMYU library was based on the need to automate the routine library operations and services ranging from acquisition, cataloguing, circulation and serials control for efficient service delivery. (UMYU library, 2016)

Meanwhile, being the only viable option to achieve the desired objectives, KOHA's free and open source status have made it adaptable in all situations, thereby providing users with the right to copy, study, edit and make the software better.

The library implemented its first automation project using WAMP system, i.e. a windows version of KOHA 2.2.9 in the year 2010. Retrospective conversion from legacy system is a fear factor for many libraries with huge collection of records. UMYU library was able to overcome the situation with the help of appropriate, cost-effective open source automation solution by relying on their own staff.

Consequently, after a series of surveys, analyses, evaluations, deliberations and considerations by an expert committee, the library finally switched from WAMP to LAMP (Linux-based) system in the year 2012.The UMYU library KOHA ILS version 3.0.6 currently runs on a Linux OS platform with 500 GB HDD installed from Project link Consult Limited. Moreover, resources captured in the system include printed books, eBooks, e-journals which are all made available and accessible to all registered users.

\section{CHALLENGES ASSOCIATED WITH THE AUTOMATION PROJECT}

\section{A. Existing Data are not in Standard Format}

The existing data of Umaru Musa Yar'adua University Library Management System (UMYULMS) is not in standard format. That means, though, a huge amount of time and cost has been wasted to input these data here in our current database, but, everything appears to be meaningless. More than 95\% data are not in standard format. That s why, when we are implementing this new system KOHA here in our library, we faced a lot of troubles regarding this conversion. Now, we are inserting each and every book`s information from the scratch.

\section{B. The University Library Management System is not Upgraded}

UMYULMS was installed in 2010. And, even now, in 2016, it has not been upgraded. That means, we are using eight (4) years old software in our library. And, as much as it is getting older, it is creating problem day by day. Example: 
Z39.5 catalogue search and import feature worked for the first two (2) years, but now, it is worthless.

\section{Poor Internet Connectivity}

Ever since its implementation, the system remains accessible only on the intranet which means it can only be accessed only on the institutional LAN and only within the campus.

\section{METHODOLOGY}

This study is quantitative and survey research method was employed. According to Cohen (2005) quantitative research is defined as social research that employs empirical statements. It is considered as numerical representation of observations for the purpose of explaining the phenomena that those observations reflect.

Survey technique is chosen for this study because of its relevance in term of efficiency and usefulness in collecting data for acceptable outcome or result for the study.

The population of the study comprises of the library staff of UMYU. Therefore, a total of thirty eight (38) staff was found to be the target population for the study. The population of the study is relative within a manageable number, it was considered unnecessary to draw any sample. In other words, the respondents are within a manageable level.

Toluhi (2001) suggested that, "if the general population of the study is too small to take a sample out of it, the use of the entire population will yield a effective research" Thus, all the operational staff were the respondents of this study. Questionnaires was designed and used as instrument for data collection.

\section{FINDINGS AND DISCUSSION}

Out of 42 questionnaires distributed, 38 were recovered and found useful for the study. As per the feedback collected from the respondents, maximum KOHA users are from Cataloguing, classification and circulation sections.

The administration is another department having a significant number of KOHA users, thus revealing the better popularity of the software in the library operations and administration.

The reason for this popularity could be that the University's focus and interest are mostly in the application of KOHA to the above mentioned operations and therefore took initiatives to conduct a significant number of KOHA workshops on cataloguing and circulating.

\section{DEVELOPMENTAL STAGES OF THE AUTOMATION PROJECT}

TABLE I THE DEVELOPMENTAL STAGES OF KOHA SYSTEM AND THE SERVICES AUTOMATED IN UMYU LIBRARY

\begin{tabular}{|c|l|c|c|c|}
\hline $\begin{array}{c}\text { Sl. } \\
\text { No. }\end{array}$ & $\begin{array}{c}\text { Services } \\
\text { automated }\end{array}$ & Proposed & Partially & Completed \\
\hline 1 & Acquisition & $34(89.5 \%)$ & $3(7.9 \%)$ & $1(2.6 \%)$ \\
\hline 2 & Cataloguing & $2(5.3 \%)$ & $6(15.8 \%)$ & $30(78.9 \%)$ \\
\hline 3 & Reference & $2(5.3 \%)$ & $32(84.2 \%)$ & $4(10.5 \%)$ \\
\hline 4 & Circulation & $0(0.0 \%)$ & $4(10.5 \%)$ & $34(89.5 \%)$ \\
\hline 5 & Serials & $32(84.2 \%)$ & $6(15.8 \%)$ & $0(0.0 \%)$ \\
\hline 6 & Administration & $34(89.5 \%)$ & $4(10.5 \%)$ & $0(0.0 \%)$ \\
\hline
\end{tabular}

The table above shows that the majority of respondents 34 (89.5\%) indicates that, circulation has the highest level of automation in UMYU library. This is followed by Cataloguing 30 (78.9\%), Reference indicated partially 32 $(84.2 \%)$, it is also indicates a large number of the staff 34 (89.5\%) opined that acquisition and administration were on proposed stage respectively. While reference services are at a partial level with a total number of 32 (84.2\%) responses.

Based on the responses as observed, the two main services fully automated were the Circulation and Cataloguing for the library understudy.

\section{REASONS FOR THE ADOPTION AND IMPLEMENTATION OF KOHA ILS IN UMYU LIBRARY}

TABLE II THE REASONS FOR THE ADOPTION AND IMPLEMENTATION OF KOHA FOR AUTOMATION OF UMYU LIBRARY

\begin{tabular}{|c|l|c|c|c|c|}
\hline Sl. No. & \multicolumn{1}{|c|}{ Reasons } & Strongly agreed & Agreed & Disagreed & Strongly disagreed \\
\hline 1 & Collection growth & $6(15.8 \%)$ & $30(78.9 \%)$ & $2(5.3 \%)$ & $0(0.0 \%)$ \\
\hline 2 & Library extension & $4(10.5 \%)$ & $28(73.7 \%)$ & $4(10.5 \%)$ & $2(5.2 \%)$ \\
\hline 3 & Its secure & $7(18.4 \%)$ & $28(73.7 \%)$ & $3(7.9 \%)$ & $0(0.0 \%)$ \\
\hline 4 & NUC’s requirement & $2(5.3 \%)$ & $18(47.3 \%)$ & $8(21.1 \%)$ & $10(26.3 \%)$ \\
\hline 5 & Open source (free software) & $30(78.9 \%)$ & $8(21.1 \%)$ & $0(0.0 \%)$ & $0(0.0 \%)$ \\
\hline 6 & Easy to use & $18(47.3 \%)$ & $17(44.8 \%)$ & $3(7.9 \%)$ & $0(0.0 \%)$ \\
\hline 7 & It's affordable & $20(52.6 \%)$ & $18(47.3 \%)$ & $0(0.0 \%)$ & $0(0.0 \%)$ \\
\hline 8 & $\begin{array}{l}\text { Greater opportunities for } \\
\text { innovation }\end{array}$ & $30(78.9 \%)$ & $8(21.1 \%)$ & $0(0.0 \%)$ & $0(0.0 \%)$ \\
\hline
\end{tabular}


Table II above reveals that majority of responses 30 (78.9\%) confirmed that KOHA ILS was chosen as it was a free open source, similarly 30 (78.9\%) were opined that, the KOHA was chosen as a great opportunity for innovation and for the collection grows respectively for the library understudy. Meanwhile, responses show that 20 (52.6\%) indicates that the KOHA was chosen due to its affordable.
Others indicate that 28 (73.7\%) due to library extension, and because it was secure respectively. It is evident that, the library understudy adopted the use of the KOHA ILS as it was a free open source and secondly for Greater opportunities and innovation.

\section{CHALLENGES AND EXPERIENCE OF UMYU LIBRARY IN THE IMPLEMENTATION OF KOHA ILS}

TABLE III CHALLENGES ASSOCIATED WITH KOHA IMPLEMENTATION PROJECT

\begin{tabular}{|c|l|c|c|c|c|}
\hline Sl. No. & \multicolumn{1}{|c|}{$\begin{array}{c}\text { Challenges of KOHA System } \\
\text { Implementation }\end{array}$} & Strongly Agreed & Agreed & Disagreed & Strongly Disagreed \\
\hline 1 & Retrospective conversion & $34(89.5 \%)$ & $4(10.5 \%)$ & $0(0.0 \%)$ & $0(0.0 \%)$ \\
\hline 2 & Wrong choice of software version & $0(0.0 \%)$ & $0(0.0 \%)$ & $32(84.2 \%)$ & $6(15.8 \%)$ \\
\hline 3 & Epileptic power supply & $8(21.1 \%)$ & $28(73.7 \%)$ & $2(5.2 \%)$ & $0(0.0 \%)$ \\
\hline 4 & Lack of well trained staff & $2(5.2 \%)$ & $6(15.8 \%)$ & $28(73.7 \%)$ & $2(5.2 \%)$ \\
\hline 5 & Low level of user literacy & $6(15.8)$ & $30(78.9 \%)$ & $1(2.6 \%)$ & $1(2.6 \%)$ \\
\hline 6 & Lack of user awareness & $4(10.5 \%)$ & $28(73.7 \%)$ & $2(5.2 \%)$ & $2(5.2 \%)$ \\
\hline 7 & $\begin{array}{l}\text { Lack of regular update/upgrade of } \\
\text { software }\end{array}$ & $20(52.6 \%)$ & $15(39.4 \%)$ & $3(7.9 \%)$ & $0(0.0 \%)$ \\
\hline 8 & $\begin{array}{l}\text { Librarians' unwillingness to accept } \\
\text { change }\end{array}$ & $0(0.0 \%)$ & $2(5.2 \%)$ & $28(73.7 \%)$ & $8(21.1 \%)$ \\
\hline 9 & Perceived difficulty of use. & $3(7.9 \%)$ & $20(52.6 \%)$ & $10(26.3 \%)$ & $5(13.2 \%)$ \\
\hline
\end{tabular}

Table above shows that Retrospective conversion constant or occasional breakdown, which account strongly agreed 34 (89.5\%) followed by Low Level of Literacy 30 (78.9\%). The responses further indicate the lack of user awareness 28 (73.7\%) and Epileptic power supply respectively. Lack of regular update/upgrade of software $20(52 \%)$ as indicated is also a challenge.

The table, however reveals that respondents 32 (84.2\%) disagreed that Wrong choice of software version were among the challenges for the implementation of KOHA ILS in the library understudy. Similarly, respondents 28 (73.7\%) disagreed that Librarians' unwillingness to accept change were among the challenges and so also 28 (73.7\%) faulted the Lack of well trained staff as a challenge.

From the result above, therefore we can deduce that Retrospective conversion and Low Level of Literacy were the major challenges and a setback for the KOHA ILS implementation in UMYU library.

\section{RECOMMENDATION}

1. The two main services fully automated were the Circulation and Cataloguing; there is the need to focus more on other services like Acquisition, Administration and Serial services so to achieve full automation of the library.

2. Library adopted the use of the KOHA ILS as it was a free open source and secondly for Greater opportunities and innovation. The library therefore must ensure that choosing the right version of the software is relatively good and saves unnecessary waste of resources and time.

3. Retrospective conversion, Low Level of Literacy and Lack of regular upgrade of software were the major challenges and a setback for the KOHA ILS implementation in UMYU library. The library understudy should continue to train staff, especially regular in-house training for the staff and User orientation. To achieve a better result, regular update/upgrade of software is necessary.

\section{REFERENCES}

[1] Cohen, K. (2005).Information Technology in Developing Countries, System Research, 1(1)10. New York City School Library System Handbook (2007). Automation. Retrieved from: http://schools.nyc.gov/NR/rdonlyres/D0544E4C-45EC-4038-BA78 616DB87C193A/33417/Section311Automation.pdf on 23rd October, 2020

[2] Imo, Nwabuisi T. and Igbo, Uche H. (2011). The Challenges of Software Use in Nigerian University Libraries: Review of Experiences from 1990-2009. Library Philosophy and Practice. Retrieved from: http://unllib.unl.edu/LPP/ on $25^{\text {th }}$ October, 2020

[3] Kumar, Vimal \& Jasimudeen S. (2012). The Adoption and User Perceptions of KOHA Library Management System in India. Annals of Library and Information Studies, 59, December 2012, 223-230. Retrieved from: http://eprints.rclis.org/18198/1/ALIS\%2059(4)\% 20223-230.pdf

[4] Nok, Grace (2006). The Challenges of Computerising University Libraries in Nigeria: The Case of Kashim Ibrahim Library, Ahmadu Bello University, and Zaria: Library Philosophy and Practice (ejournal), 2(8) 6-8.

[5] Microsoft ® Encarta ${ }^{\circledR}$ 2009. (C) 1993-2008 Microsoft Corporation. All rights reserved. 
[6] Oladokun, S. O. \& Ogunrombi, S. A. (1992). TINLIB: Application for Library Automation in a Nigerian Universities of Technology: Journal of the Nigerian Library Association, 25 \& 26(1-4), 1-8.

[7] Okentunji, Ibidapo (2006). The Choice of Library Application Softwares, their Sustainability: Necessary Guidelines. Current trends in ICTs: Application to Technical Service, Abuja: NLA (Cal \& Class Section).

[8] Sheikh, R. A. \& Jan, S. U. (2011). Automation of University Libraries: A Comparative Analysis of Islamabad and Khyber
Pukhtoon Khwa, Pakistan: Library Philosophy and Practice. Retrieved from: http://unllib.unl.edu/LPP/ on $25^{\text {th }}$ October, 2020

[9] Toluhi, J.O. (2001). Fundamentals of research methodology, Ilorin, Nigeria: Victory Publications

[10] Umaru Musa Yar'adua University (2012). students’ library guide: UMYU Press, Katsina

[11] Umaru Musa Yar'adua University (2016). students’ library guide: UMYU Press, Katsina 